ОСОБИСТІСНО ОРІЄНТОВАНИЙ ПІДХІД

ДО ПРОФЕСІЙНОЇ ДІЯЛЬНОСТІ ЗАСОБАМИ ОРГАНІЗАЦІЇ

САМОСТІЙНОЇ РОБОТИ МАЙБУТНІХ ПСИХОЛОГІВ

\title{
PERSONALITY-ORIENTED APPROACH TO PROFESSIONAL ACTIVITY BY MEANS OF ORGANIZING INDEPENDENT WORK OF FUTURE PSYCHOLOGISTS
}

У статmі розглянуто теоретичні засади особистісно-орієнтованого підходу до організації самостійної роботи студентів 3 опанування навчальних дисциплін у процесі фрахової підготовки майбутніх психологів, а також запропоновано методи ї вдосконалення. Акцентована увага на тому, що освітня галузь в Україні, ставши на шлях кардинальних ресрорм входження до європейського освітнього простору, потребує приведення всіх їі компонентів до загальноприйнятих світових стандартів. У сучасному світі особливої ваги набуває поняття якості освіти. Рух держави до високої якості освіти не є простим. Він потребує значних затрат інтелектуальних ресурсів та організованої на засадах особистої організаційної культури самоосвітньої діяльності здобувача освіти. Входження нашої держави до єдиного європейського освітнього простору вимагає підготовки фрахівця вищої кваліфікації, запровадження єдиного додатка до диплома, забезпечення вільного переходу студентів на навчання до інших європейських країн, створення європейської зони вищої освіти як засобу підвищення мобільності та працевлаштування молоді у відповідності до глобальних суспільних запитів. На підставі аналізу результатів досліджень вітчизняних та зарубіжних учених із проблеми організації самостійної позааудиторної роботи студентів психологічного просрілю встановлено, що їхня самостійна робота сприймається переважно або як організаційна форма, або як метод навчання, що використовують викладачі й студенти для засвоєння знань і формування самостійності в організації опанування навчальних дисциплін. Самостійна освітньо-пізнавальна робота студентів розглядається як важлива форма організації навчання, що включає різні вектори індивідуальної і групової діяльності та здійснюється на навчальних занят тях або в позааудиторний час. Теоретичний аналіз психолого-педагогічної літератури щодо професійної підготовки майбутнього психолога засвідчив, що самостійна робота студентів на засадах особистісно-орієнтованого підходу до організації самостійноі роботи студентів з опанування навчальних дисциплін виконує ряд функцій (освітню, пізнавальну, коригуючу, стимулюючу, виховну i розвиваючу) і поділяється на різні види, залежно від критеріїв, покладених в основу класифрікації. Самостійна робота у закладі вищої освіти (ЗВО) передбачає поетапне засвоєння нового матеріалу, його закріплення, застосування на практиці, повторення матеріалу. Ефективність самостійної роботи залежить від ії організації, змісту, взаємозв'язку, характеру завдань та результатів ї̈ виконання

Встановлено, що самостійна робота має певні особливості, які відрізняють ї̈ від освітньо-пізнавальної діяльності в цілому: вона планується викладачем, який організовує іï, визначає обсяг, зміст, терміни виконання, час, форму контролю, але здійснюється без його безпосередньої участі. Такому засобу організації освітньо-пізнавальної діяльності сприяють сорормульовані В.О. Сухомлинським принципи особистісно-орієнтованого підходу, що представляються особливо чінними в процесі фрахової підготовки майбутніх психологів.

Ключові слова: самостійність, особистість, особистісно-орієнтований підхід, мотивація.

The article reviews the theoretical principles of person-centered approach to independent work of students from disciplines of professional training of students and asked one of the methods of its improvement.

The article discusses the theoretical foundations of a personality-oriented approach to the organization of independent work of students in the development of academic disciplines in the process of professional training of future psychologists, and also suggests methods for its improvement. Attention is focused on the fact that the sphere of education in Ukraine, having embarked on the path of cardinal reforms of entering the European educational space, requires bringing all its components to the generally accepted world standards. In the modern world, the concept of the quality of education is of particular importance. The government's movement towards high quality education is not easy. It requires a significant investment of intellectual resources and self-educational activities organized on the basis of the personal organizational culture of the applicant for education. The entry of our state into a single European educational space requires the training of a highly qualified specialist, the introduction of a single supplement to the diploma, ensuring the free transfer of students to study in other European countries, the creation of a European higher education zone as a means of increasing the mobility and employment of youth in accordance with global public needs.

Based on the analysis of the research results of domestic and foreign scientists on the problem of organizing independent extracurricular work of students of a psychological profile, it was found that their independent work is perceived mainly as an organizational form, or as a teaching method, used by teachers and students to assimilate knowledge and form independence in the organization of mastering educational disciplines. Independent educational and cognitive work of students is considered as an important form of organizing training, including various vectors of individual and group activities and is carried out in the classroom or during extracurricular time. A theoretical analysis of psychological and pedagogical literature on the professional training of a future psychologist showed that the independent work of students 
on the basis of a personality-oriented approach to organizing students' independent work on mastering academic disciplines performs a number of functions (educational, cognitive, corrective, stimulating, educational and developmental) and is divided into different types, depending on the criteria underlying the classification. Independent work in an institution of higher education (HEl) provides for the gradual assimilation of new material, its consolidation, application in practice, and repetition of the material. The effectiveness of independent work depends on its organization, content, relationship, the nature of the tasks and the results of its implementation.
It was found that independent work has certain features that distinguish it from educational and cognitive activity in general: it is planned by the teacher, who organizes it, determining the volume, content, timing, time, form of control, but is carried out without his direct participation. The organization of educational and cognitive activity is promoted by the principles of a personality-oriented approach, formulated by V. A. Sukhomlinsky and are especially valuable in the process of professional training of future psychologists.

Key words: independence, personality, personality-oriented approach, rating, motivation, credit-modular system.
То, чего человек не приобрел путем своей самостоятельности, - не его.

Ф.А. Дистервер

Постановка проблеми у загальному вигляді. Реформування освіти в Україні передбачає створення умов для особистісного розвитку і творчої самореалізації кожного громадянина України. Це сприятиме підвищенню інтелектуального потенціалу нації, всебічному розвитку особистості як найвищої цінності суспільства. Головною педагогічною ідеєю сучасності стає освіта впродовж життя. її реалізація потребує значної уваги до загального розвитку особистості, її когнітивнотворчих, комунікативних здібностей, самостійності в прийнятті рішень, здобутті нових знань.

Враховуючи тенденції соціально-економічного розвитку України, прогнозованим $€$ зростання попиту на компетентних випускників закладів вищої освіти. Ці тенденції враховуються і в організації освітнього процесу з метою фрормування професійно необхідних якостей у майбутнього фахівця. Згідно з навчальним планом закладу вищої освіти, значну частину становить самостійна робота студентів. Таке навчання стимулює самостійність молодої людини, що в кінцевому результаті позитивно впливає на розумові здібності й риси особистості. Вільне від зайвого опікування навчання стимулює вироблення гнучкого, творчого стилю мислення, самодостатності, вміння приймати власні рішення, швидко адаптовуватися в оточуючому середовищі.

Самостійна робота $€$ найважливішим компонентом педагогічного процесу, що передбачає інтеграцію різних видів індивідуальної та колективної навчальної діяльності, яка здійснюється як під час аудиторних, так і позааудиторних занять, без участі викладача та під його безпосереднім керівництвом. У контексті сучасної парадигми навчання самостійна робота домінує серед інших видів навчальної діяльності студентів та дозволяє розглядати знання як об'єкт власної діяльності студента. Пізнавальна діяльність студентів у процесі виконання самостійної роботи характеризується високим рівнем самостійності та активності, являється залученням суб'єкта до творчої діяльності.
Аналіз останніх досліджень і публікацій. Питання організації самостійної роботи студентів завжди було актуальним у системі освіти вищої школи. Із загальнотеоретичних позицій шляхи вирішення цієї проблеми розкриваються в працях Г. Александрова, С. Архангельського, Є. Малібоги, Н. Тализіної та інших. Проблема самостійної роботи майбутніх психологів посіла провідне місце в дослідженнях багатьох педагогів та психологів (Ю. Бабанського, О. Бондарчук, С. Максименка, О. Мороза, А. Петровського, Г. Костюка, О. Леонтьєва, Л. Карамушки, Н. Чепелевої та ін.).

Самостійна робота, як дидактична категорія, підлягає аналізу в ряді досліджень (М. Данілова, М. Левіна, І. Огороднікова, Т. Шамової тощо).

Згідно з Б. Єсиповим, самостійна робота студентів - це робота, яка виконується без безпосередньої участі викладача, але за його завданням у спеціально наданий для цього час, при цьому студенти свідомо намагаються досягти поставленої мети, проявляючи зусилля і виражаючи в тій чи іншій фрормі результати своїх розумових дій. Г. Новосьолов уважає, що самостійна робота представляє собою пізнавальну діяльність, у процесі якої студент активно сприймає й осмислює знання, поглиблює і розширює отриману в готовому вигляді інформацію, створює нову і застосовує її на практиці, оволодіває відповідними професійними вміннями.

Ґрунтуючись на дослідженнях А. Алексюка, Б. Єсипова, П. Підкасистого, О. Савченко, самостійна робота студентів як особлива форма розглядається як вид навчальної діяльності, в процесі якої вони оволодівають знаннями і вміннями, а також розвивають такі якості, як самостійність і активність.

Мета статті - проаналізувати теоретичні засади особистісно-орієнтованого підходу в організації самостійної роботи майбутніх психологів та позиціонувати шляхи її вдосконалення.

Виклад основного матеріалу. Сучасний, а тим більше майбутній динамізм зміни знань, інформації, технологій означає, що навчити навіть у найкращому університеті людину на все життя неможливо. Рано чи пізно вона втратить конкурен- 
тоспроможність, стане фрункціонально недієздатною, якщо не поповнюватиме і не оновлюватиме знання. Виникає потреба розуміння студентом необхідності та вміння самостійно навчатись упродовж життя [6].

Дослідження Н. Аверіна, Ю. Бабанського, Н. Тализіної переконують, що вміння вчитися означає вміння самостійно осягати таємниці навколишнього світу, володіти здатністю перетворювати світ, робити його досконалішим. Це загальне вміння містить такі види діяльності:

а) раціональне використання часу;

б) здатність пошуку потрібної інфрормації;

в) робота 3 довідковою літературою (підручниками, довідниками, журналами, персональними комп'ютерами тощо);

г) виділення головного, суттєвого в прочитаному та складання конспекту;

д) доведення розпочатої справи до кінця.

Для майбутніх психологів необхідно усвідомити, що самостійність є найважливішою професійною психічною якістю, яка характеризує здатність систематизувати, планувати та регулювати свою діяльність без безпосереднього постійного керівництва та практичної допомоги з боку керівника, вважають К. Платонов та Г. Голубєв [9].

Розглядаючи проблему організації самостійної роботи студентів, необхідно розглянути сутність явища самостійність.

Н. Конюхова виділяє такі характерні особливості змісту поняття самостійність: це здатність особистості, тобто психічна риса індивіда, яка регулює його поведінку та $є$ умовою його життєдіяльності; всі дії самостійна особистість здійснює без керівництва і такої ж допомоги з боку керівника; самостійна діяльність допускає опосередковані керівництво та допомогу, тобто самостійна людина в самостійних діях теж має чимось керуватися; всі дії здійснюються без постійного керівництва викладача, тобто можна припустити епізодичне втручання в самостійну діяльність; самостійність можна характеризувати вмінням щодо систематизації, планування, прийняття рішень, відповідальності за всі свої дії, регулювання їх [5].

Лише завдяки власній діяльності з появою внутрішньої потреби в знаннях, пізнавальних інтересах, захопленості проявляється самостійність у здобутті знань. Чи не єдиним способом виховання самостійності в набутті знань майбутніх психологів у процесі фрахової підготовки виступає самостійна робота. Високо оцінюючи роль самостійної роботи в процесі навчання, Я.А. Коменський наголошував: «Альфою та омегою нашої дидактики нехай буде пошук і відкриття способу, за якого б учителі менше навчали, а учні більше б училися» [4]. Ця дидактична аксіома актуальна і в сучасну історичну добу.
Натомість одним із головних напрямів, що веде до покращення якості підготовки спеціаліста, $€$ його готовність до самостійної творчої діяльності, яка фрормується протягом навчання в закладі вищої освіти. Самостійна робота студентів має спрямовуватися на реалізацію таких тісно пов'язаних завдань, як: розвиток у студентів самостійності, вміння здобувати знання та здатність студентів самостійно використовувати ці знання в практичній площині професійної діяльності. Адже молоді люди, в яких сорормовані навички самостійної роботи, активніше й ефективніше засвоюють необхідні професійні постулати, не губляться в проблемах мегаполісу, краще підготовлені до самоосвіти, більш кваліфіковано вирішують проблеми сучасного соціуму.

Сучасні дослідники по-різному трактують сутність самостійної роботи в процесі підготовки майбутнього психолога, по-різному її визначають. Одні вважають, що самостійна робота студентів $€$ необхідним елементом будь-якого методу навчання у ЗВО. Прибічники цієї точки зору практично ототожнюють самостійну роботу із самостійною діяльністю. Згідно з цією точкою зору за самостійну можна вважати тільки таку роботу, за якої студент без допомоги викладача проаналізував та узагальнив навчальний матеріал, перевірив свої висновки та результати. У свою чергу більшість дослідників трактують самостійну роботу як обов'язок студентів, передбачений навчальним планом, де виділені години для самостійної позааудиторної роботи.

Наприклад, П. Підкасистий відзначає, що цей засіб навчання $€$ найважливішою умовою самоорганізації і самодисципліни того, хто навчається, в опануванні методів пізнавальної діяльності, виробляє в нього психологічну установку на самостійне систематичне поповнення власних знань і набуття вмінь орієнтуватися в потоці наукової і політичної інсрормації у процесі розв'язування нових пізнавальних задач. Самостійну роботу у вищій школі він розглядає як специфічний засіб організації навчання, який: у конкретній ситуації засвоєння відповідає конкретній дидактичній меті й пізнавальному завданню; сприяє фрормуванню у студента на кожному етапі його просування від невідомого до відомого обсягу і рівня знань, умінь і навичок, необхідних для розв'язання певного класу пізнавальних завдань, і, відповідно, просування його від нижчих до вищих рівнів розумової діяльності; дозволяє виробити у студента психологічне настановлення на самостійне систематичне поповнення своїх знань і умінь з орієнтування в потоці наукової і спеціальної літератури, розв'язання навчальних, наукових та виробничих завдань; виступає важливим знаряддям педагогічного керування самостійною пізнавальною діяльністю студента в процесі навчання [8]. 
Спроби з'ясувати означення поняття «самостійна робота» зустрічаються також у працях І. Зязюна, який розуміє під самостійною роботою діяльність, що її виконують ті, хто навчається, 3 максимальною активністю, творчістю, самостійним судженням, ініціативністю [3].

На думку А.М. Алексюка, самостійність у здобутті знань передбачає оволодіння вміннями і навичками бачити зміст та мету роботи, організовувати власну самоосвіту, вміння по-новому підходити до вирішуваних питань, пізнавальну й розумову активність і самостійність, здатність до творчості [1]. Це означення певною мірою дає уявлення про необхідність створення умов, за яких студенти будуть добре усвідомлювати важливість самоосвіти й самостійної роботи, що сприятиме підвищенню її ефрективності.

У нашому дослідженні ми трактуємо самостійну роботу майбутніх психологів як один із видів підготовки до самостійної професійної діяльності; тому самостійну роботу визначаємо як специфічну форму діяльності вчення, якій властива двоєдина мета: формування самостійності та розвиток життєвих і професійних компетентностей студентів. Досліджуючи проблему самостійної роботи у процесі фрахової підготовки, ми звернули увагу на тісний взаємозв'язок самостійної роботи студентів і ефрективності їхньої профресійної підготовки.

Вітчизняний дидакт В. Луценко переконує, що рівень організації самостійної діяльності значно впливає на формування у студентів-психологів стійкого інтересу до навчальних дисциплін, на ступінь їхньої пізнавальної активності та на процес оволодіння як відповідним інорормаційним змістом, так і професійними компентностями [7].

Підходи зарубіжних дидактів характеризуються більшою різноманітністю щодо самостійної роботи. Серед різних підходів дидактів зі США до цієї проблеми можна виділити два протилежних:

- навчання за умови обов'язкового керівництва викладача;

- незалежне навчання, коли студент користується великою свободою вибору як матеріалу, так і засобів його засвоєння.

У Німеччині виділяють такі аспекти самостійної роботи:

- робота студента здійснюється під непрямим керівництвом викладача - опосередковане навчання;

- директивне навчання під керівництвом викладача;

- «вільна» розумова робота студента, яка характеризується можливістю вибору засобів і мети ним самим.

Педагоги Франції користуються як терміном «індивідуальна робота», так і терміном «вільна діяльність», коли передбачається наявність інтересів та ініціативи студентів.
На думку вітчизняного вченого В. Буряка, самостійна робота студентів є одним із головних методів оволодіння знаннями і навичками в процесі навчання у вищій школі, оскільки вона фрормує в студентів потребу у творчій пізнавальній діяльності, посилює активізацію думки, вимагає постійної самоосвіти. Самостійна робота виконує пізнавальну, навчальну й виховну функції в навчальному процесі. Завдяки їй підвищується активність, інтерес студентів. Самостійна робота озброює їх системою наукових знань і навичок, розвиває творчі здібності та дарування, направляє діяльність на актуалізацію знань, умінь і навичок для вирішення нових завдань [2].

Вибір видів самостійної роботи майбутніх психологів у ЗВО залежить не лише від змісту навчального матеріалу, його також визначають фрункції, які виконує самостійна робота в освітньому процесі. До основних функцій відносять навчальну, пізнавальну, прогностичну, стимулювальну, реалізаційну, діагностичну, самоосвітню та виховну. Кожна з них має свою характеристику.

Сутність навчальної функції полягає в набутті студентами нових знань, навичок самостійного їх оновлення і застосування, в оволодінні методами, раціональними засобами розумової діяльності.

Пізнавальна ффункція у процесі самостійної роботи студентів сприяє активному закріпленню тих знань, які вони одержали під час аудиторних занять, та потребує активних дій студентів у виконанні практичних завдань.

Прогностична фрункція дає можливість майбутнім психологам, працюючи самостійно, передбачати й оцінювати можливий результат роботи, прогнозувати власну освітню діяльність.

Зміст стимулювальної фрункції зводиться до того, що відчуття особистих досягнень, задоволення власною працею заохочують студентів до організації плідної роботи над усвідомленням правильності вибору профресійного шляху.

За допомогою реалізаційної фрункції через систему типових завдань із практичним змістом навчальна діяльність у ЗВО наближається до майбутньої фрахової, і вже на перших етапах навчання реалізується його професійний зміст.

Діагностична фрункція втілюється в тому, що за допомогою самостійної роботи забезпечується моніторинг знань і вмінь. Результати роботи інформують викладача про рівень засвоєння навчального матеріалу.

Сутність самоосвітньої функції полягає в тому, що в ході самостійної роботи в особистості розвивається потреба в самостійному здобуванні знань, фрормуються відповідні вміння й навички. Ця фрункція набуває особливого значення в контексті євроінтеграційних процесів. Нині Україна знаходиться на шляху до входження в Європейський простір вищої освіти, проголошений Болонською конвен- 
цією, одна із провідних ідей якої - навчання протягом усього життя. У сучасних умовах швидкого накопичення й оновлення інфрормації того обсягу знань, якими студент оволодіває за роки навчання у ЗВО, вже не буде достатньо для забезпечення професійної компетентності, тому освіта повинна стати неперервною.

Виховна функція. її вагомість підтверджують Закон України «Про вищу освіту» та «Національна доктрина розвитку освіти України в XXI столітті», де проголошується одним із завдань фрормування у дітей та молоді сучасного світогляду, розвитку творчих здібностей і навичок самостійного наукового пізнання, самоосвіти і самореалізації особистості; підготовки кваліфрікованих кадрів, здатних до творчої праці, професійного розвитку.

Природні задатки, нахили, обдарування становлять зміст індивідуальних особливостей студентів, а їх виявлення - зміст особистісно-орієнтованого підходу - урахування індивідуальних особливостей у процесі фрахової підготовки майбутніх психологів. У свою чергу, розкриваючи сутність особистісно-орієнтованого підходу до навчання й виховання, педагогіка вищої школи трактує важливим принципом, що випливає із педагогічних ідей В. Сухомлинського, принцип визнання кожного студента особистістю.

У психолого-педагогічній літературі виділяють три рівні пізнавальної самостійності особистості: репродуктивний, частково-пошуковий, творчий, які у свою чергу тісно пов'язані з трьома рівнями мислення (активне, самостійне, творче) [10]. На репродуктивному - студент повинен засвоїти вже готові знання. Частково-пошуковий рівень характеризується частковою організацією процесу одержання інфрормації безпосередньо пошукувачами освітніх послуг. Дії студентів на творчому рівні повністю самостійні. Досягнення найвищої самостійності в навчанні характеризується здатністю окреслити проблему й визначити шляхи для її розв'язання. Потрібно зауважити, що іноді й виконання певних завдань репродуктивного характеру змушує студентів працювати на досить високому рівні самостійності. Наприклад, у процесі підготовки виступу 3 доповіддю 3 нової теми йому доведеться самостійно відшукати й відібрати інформацію в наукових джерелах, проаналізувати й систематизувати іiі. Отже, для встановлення рівня самостійності необхідно співвідносити зусилля, витрачені на одержання результату, з пізнавальними можливостями особистості студента.

Для поглибленого аналізу стану організації самостійної роботи в ДЗВО «Університет менеджменту освіти» здійснено анкетування групи другого курсу (28 майбутніх психологів) для визначення рівня сорормованості профресійного інтересу на початковому етапі ознайомлення з вибраною спеціальністю, після вивчення дисципліни «Вступ у спеціальність». Результати анкетування свідчать, що значна кількість студентів (50\%) має високий рівень сорормованості інтересу до майбутньої професії; 35\% - допускають імовірність щодо використання здобутих знань у майбутній діяльності; $15 \%$ - взагалі не уявляють, як їхні знання можуть бути використані на практиці (рисунок 1).

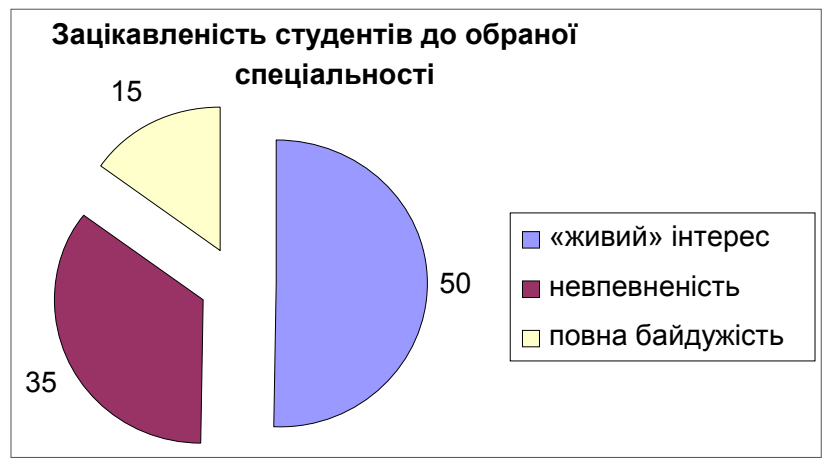

Рис. 1. Професійна спрямованість майбутніх психологів

Стосовно матеріалу, який майбутні психологи хотіли би вивчати в позааудиторний час, 26\% вважають за необхідне використовувати профресійну і практичну спрямованість матеріалу (спецкурси, тренінги, супервізійну консультативність). Таким чином, узагальнення результатів аналізу дало змогу дійти висновку, що саме врахування потреб та інтересів студентів щодо організації роботи в позааудиторний час, використання професійно спрямованого матеріалу є необхідними умовами підвищення ефективності самостійної позааудиторної діяльності.

щоб зацікавити молодих людей продовжувати вдосконалення своїх знань після занять, діяльність педагога має носити творчий характер. Уміння передати студентам не лише свої знання, a і власний досвід, ставлення до предмета, визначається особистістю й майстерністю викладача. Високий рівень професійної майстерності передбачає повсякчасне вивчення свого предмета, вдосконалення техніки його викладання.

Найважливішими якостями, якими, на думку студентів, має володіти викладач для ефективної організації самостійної позааудиторної роботи студентів, є досконале володіння своїм предметом, методична майстерність.

Активізації навчальної діяльності сприяє також наявність системи у використанні навчальних диореренційованих тестів різних ступенів складності, багатоваріантних завдань, використання кросвордів, вправ із «ключами» для самоконтролю, вікторин, диспутів.

Необхідною умовою організації самостійної роботи є впорядкування навантаження на студента, що забезпечується відповідним календарним плануванням та узгодженням етапності виконання завдань самостійної роботи 3 різних навчальних 
дисциплін. Велике значення в самостійній навчальній діяльності майбутніх психологів відіграє вільний вибір теми, форми й часу виконання роботи. Тому в системі самостійного навчання важливе місце займають творчі завдання: доповіді, огляди тощо. Ці завдання спонукають студента досліджувати, оскільки охоплюють широкий діапазон матеріалів від огляду літератури, преси до власних роздумів із приводу досліджуваної теми. Лише такі підходи мотивують майбутніх психологів до постійної і активної розумової діяльності як в аудиторії, так і поза нею. Особливо це стосується студентів старших курсів, де обсяг матеріалу, винесеного на самостійне опрацювання, може бути значним у зв'язку з виконанням курсових або дипломних робіт.

Запровадження модульно-рейтингової системи оцінювання знань зумовлено тим, що діюча чотирибальна система не задовольняє ні викладачів, ні студентів, оскільки в її основі лежить низка недоліків. Рейтингова система оцінювання широко використовується в багатьох країнах світу. Рейтинг (англ. rating - оцінка, порядок, класифікація) термін, який означає суб'єктивну оцінку явища за заданою шкалою. За допомогою рейтингу здійснюється первинна класифікація соціально-педагогічних об'єктів за ступенем вираження спільної для них властивості. У педагогічних науках рейтинг служить основою для побудови різноманітних шкал оцінок, зокрема в оцінюванні різних сторін навчальної і педагогічної діяльності, популярності чи престижності професій серед молоді тощо. Одержані при цьому дані зазвичай мають характер порядкових шкал. Рейтингова система передбачає визначення рівня оволодіння студентами змістом навчального матеріалу модуля, цілісного курсу, сорормованості умінь і навичок.

У процесі фрахової підготовки майбутніхпсихологів переваги запровадження модульно-рейтингової системи оцінювання знань полягають у тому, що:

- навчальний рейтинг активізує самостійну роботу студентів, робить ії ритмічною і систематичною впродовж семестру;

- фрормується позитивна мотивація навчальної діяльності;

- стимулюється самостійність, ініціативність, відповідальність, творчість, змагальність, дбайливість;

- студент зорієнтований на самостійний науковий пошук, що сприяє інтелектуальному розвитку особистості;

- підвищується об'єктивність оцінювання знань, збільшується ймовірність уникнення ризиків у системі фрахової підготовки;

- зменшується навантаження під час екзаменів та заліків;

- фрормуються профресійні компетентності;
- отримується особисте задоволення від процесу навчання.

Для викладачів є:

- реальна можливість індивідуалізації навчання та диференційованого підходу;

- можливість допомогти студентам у навчальній роботі, рівномірно розподілити навантаження протягом семестру;

- можливість уникнути конфрліктів, які часто виникають у результаті підсумкової перевірки знань на екзаменах.

Рейтинг активізує роботу студентів протягом семестру, змушує їх працювати систематично і самостійно, вносить елементи змагання у навчальний процес, розширює можливості для всебічного розвитку, індивідуалізує навчання, істотно змінює відносини між викладачами і майбутніми психологами, створює атмосферу психолого-педагогічної взаємодії. Така система навчання дає змогу кожному здобувачеві освітніх послуг вибирати спосіб навчання та спосіб отримання оцінки з дисципліни, постійно здійснювати самоконтроль за рівнем підготовки, вносити корективи в навчальну роботу. Рейтингова система оцінювання дає змогу викладачеві отримувати повну інформацію про виконання кожним студентом графріка самостійної роботи; реалізувати прагнення до особистісноорієнтованого підходу в роботі зі студентами; сприяє активному, творчому, методично обґрунтованому викладанню дисципліни; підвищує об'єктивність оцінювання.

Висновки. Отже, враховуючи, що основними завданнями ЗВО є: забезпечення конкурентоспроможності випускників на внутрішньому і світовому ринках праці за рахунок поглиблення фрундаментальної та загальнопрофесійної підготовки і практично-орієнтованого змісту навчання; розвиток природних здібностей конкретного індивіда, формування у студентів бажання і вміння вчитися; створення передумов для саморозвитку та самореалізації особистості, то необхідно до особливих фрорм роботи з майбутніми фахівцями віднести й організацію самостійної роботи.

Натомість самостійна робота майбутніх психологів у процесі фрахової підготовки на засадах особистісно орієнтованого підходу має певні особливості, які відрізняють її від навчально-пізнавальної діяльності в цілому: вона планується студентом разом із викладачем, який організовує ії, визначає обсяг, зміст, терміни виконання, місце, час, форму звітування, але здійснюється без його безпосередньої участі. Такому засобу організації освітнього процесу майбутніх психологів сприяють принципи особистісно орієнтованого підходу, прогнозовані на підтримку і розвиток вибору професійної діяльності. 


\section{БІБЛІОГРАФІЧНИЙ СПИСОК:}

1. Алексюк А.М. Педагогіка вищої освіти України. Історія, теорія. Київ : Либідь, 1998. 286 с.

2. Буряк В. Самостійна робота як вид навчальної діяльності школяра. Рідна школа. 2001. № 9. С. 49-51.

3. Зязюн І.А. Наукове осмислення освітнього простору культури в педагогічній теорії. Імідж сучасного педагога: Науково-практичний освітньо-популярний часопис. Полтава. 2006. № 5-6. С. 12-16.

4. Коменский Я.А. Великая дидактика. Москва, 1965. $162 \mathrm{C}$.

5. Конюхова Н. Особливості організації самостійної навчально- пізнавальної діяльності студентів. Теорія та методика управління освітою. 2010. № 4. URL: http://tme.umo.edu.ua/docs/4/10koneca.pdf.
6. Королюк О.М. Дисреренціація самостійної роботи студентів коледжів технічного профілю в процесі вивчення природничо-математичних дисциплін : дис. ... канд. пед. наук : 13.00.04. Київ, 2008. 228 с.

7. Луценко В.В. Самостійна робота студентів як дидактична проблема. Науковий вісник. Серія «Філосоорія». 2001. Вип. 8. С. 63-70.

8. Перспективи розвитку коледжів і технікумів. Нарада голів Рад директорів вищих навчальних закладів I-II рівнів акредитації. Освіта України. 2007. № 1. С. 3-21.

9. Платонов К.К., Голубев Г.Г. Психология : учеб. пособие. Москва : Высш.шк., 1977. 298 с.

10. Фіцула М.М. Педагогіка вищої школи. Київ : Академвидав, 2006. 148 с. 